\title{
INPUT- AND OUTPUT-BASED GRAMMAR INSTRUCTION IN TEACHING ENGLISH AFTER GERMAN
}

\author{
Oksana Danylenko \\ postgraduate student, Ternopil Volodymyr Hnatiuk National Pedagogical University, Ternopil, \\ Ukraine, ORCID ID: https://orcid.org/0000-0003-3937-9110
}

DOI: https://doi.org/10.31435/rsglobal_ws/30062020/7116

\section{ARTICLE INFO}

Received: 08 April 2020

Accepted: 05 June 2020

Published: 30 June 2020

\section{KEYWORDS}

grammar instruction, input processing, output, grammatical competence, second language, third language.

\begin{abstract}
The article dwells on the peculiarities of instruction and the role of input and output for teaching English grammar to prospective teachers of foreign languages whose major and first foreign language is German. The aim of the survey is to analyze approaches to designing instruction for the second language grammar teaching and develop activities providing effective teaching of the grammar of English for the students with previous experience in learning German as their first foreign language. The emphasis is made on the usage of processing instruction for presenting target forms that entails input-based instruction as a means for transfer enhancement during grammar teaching and a model raising students' grammar comprehension. As far as production skills constitute one of the aspects of our investigation, we investigated the role of output-based instruction. Grammar teaching deals with grammatical forms and their usage in a particular context. Thus, developing input-based and output-based grammatical activities, we suggested activities that demonstrate the grammatical form and clarify its structure, provide possibilities for comparison of grammatical structures in English and German. The proposed output-based task provides productive grammatical skills development. The focus on form is supported with tasks explicating meaning. Consequently, the connection between grammatical form and its meaning in a certain context is provided. Tasks are communicatively oriented.
\end{abstract}

Citation: Oksana Danylenko. (2020) Input- and Output-Based Grammar Instruction in Teaching English After German. World Science. 6(58), Vol.3. doi: 10.31435/rsglobal_ws/30062020/7116

Copyright: $\left({ }^{\circ} 2020\right.$ Oksana Danylenko. This is an open-access article distributed under the terms of the Creative Commons Attribution License (CC BY). The use, distribution or reproduction in other forums is permitted, provided the original author(s) or licensor are credited and that the original publication in this journal is cited, in accordance with accepted academic practice. No use, distribution or reproduction is permitted which does not comply with these terms.

Introduction. The issue of instructed second language learning entails a wide variety of approaches to the way the grammar should be taught so that learners could benefit from this process. There is no unity among the scholars whether the instruction must be based on a focus-on-form variety of instruction or focuson-meaning, has it to be taught explicitly or should teachers resort to implicit acquisition.

The issues of pedagogy of foreign language grammar instruction are developed in the works of N. K. Sklyarenko, M. Celce-Murcia, R. Ellis, D. Larsen-Freeman, J. C. Richards, J. Scrivener, and other scholars. Though, there are the issues of the instruction under the conditions of artificial trilingualism and its peculiarities that need investigation. The aim of our study is to analyze how recent developments in the theory of grammar teaching can be applied to teaching English (L3) grammar to students whose first foreign language is German (L2) and the native language is Ukrainian (L1). Our research traces the possibilities for providing input that facilitates students' L3 grammar comprehension and output that develops production skills and fosters students' fluency.

Thus, the focus of our article is the theoretical grounds for the development of L3 grammar instruction and corresponding activities on the basis of the recent research in the area of teaching grammar of English as a second or foreign language. 
Results. The survey of recent developments in the sphere of teaching grammar shows the search for opportunities to combine focus-on-form and meaning-focused teaching options that tend to provide form-meaning balance in grammar instruction. The efficiency of focus-on-form instruction has been questioned with the development of communicative approaches to language teaching. However, the empirical evidence has been provided that the learners develop higher levels of accuracy in the second language if attention to grammatical forms is given (Nassaji \& Fotos, 2011, p. 9). The importance of form-focused instruction proves to be higher if it "takes place within communicative contexts" (Nassaji \& Fotos, 2011, p. 10). Hence teaching L3 grammar after L2 presupposes that students have experience in learning L1 as their native language and L2 as their first foreign language, to some extend the form-focused type of grammar teaching has developed their grammatical and linguistic awareness. Since the grammar instruction under the conditions of artificial trilingualism should exploit the possibilities for transfer of grammatical knowledge and provide meaningful comprehension of a new language and its grammar system.

Surveying the form-focused instruction and the efficiency of its types, Ellis (1997) differentiates between input-based and production-based instruction. Traditional grammar teaching is regarded as oriented on technics for production and output centred. Though there are investigations that support the idea that input-based instruction may be more effective for the second language acquisition due to the emphasis on conscious noticing, Ellis (1997) shows that using only positive input might be not sufficient for acquisition of grammatical features. He develops the idea of consciousness-raising that implies "the attempts to make learners aware of the existence of specific linguistic features in the target language" (Ellis, 1997, p. 85). The input flooding is viewed as insufficient to prevent fossilization. Thus, Ellis (1997) supports the use of explicit grammar instruction together with the correction of learners' errors by a teacher as the way to eliminate the negative effects in language acquisition. According to Ellis (1997), the direct instruction enhances accuracy, helps learners "progress through developmental stages more rapidly" and prevent fossilization by destabilizing interlanguage grammars (pp. 87-88). In our case, direct instruction is necessary to prevent incorrect L3 usage that is a consequence of the interaction between three grammatical systems.

Providing a further survey of grammar instruction Ellis $(2005,2014)$ proposes the set of principles for teaching grammar. One of the principles declares the necessity of extensive second language input by means of second language use enhancement during classes. Besides this, teachers have to develop resources which learners can use after classes in order to provide learners with opportunities to receive more input (Ellis, 2005, p. 217-218; Ellis, 2014, p. 38-39). We agree with these considerations for the process of teaching English takes place under the conditions of artificial trilingualism and the chances to be exposed to using L3 outside the classroom are scarce. The involvement of the elements of blended learning with online resources is one of the ways to motivate students' grammar learning and enlarge the amount of input.

The study conducted by VanPatten (1993) proves the importance of input in the second language teaching and supports the evidence that input-based instruction is more effective one, especially for the comprehension of grammar material. According to B. VanPatten (1993), the input is the beginning of grammar acquisition (p. 435). VanPatten raises the issue of intake and its role in the further acquisition of grammatical forms. He suggests that more practice has to be given to processing mechanisms that convert the input into the intake. From the point of view of psycholinguistics, grammar instruction involves "focused practice in correctly interpreting incoming utterances and in perceiving and processing those elements in the input that might otherwise be missed" (VanPatten, 1993, p. 438).

VanPatten (1993) develops the theory of processing instruction and the concept of structured input. The purpose of this type of instruction is "to direct learner's attention to relevant features of grammar in the input and to encourage correct form-meaning mappings that in turn result in better intake" (VanPatten, 1993, p. 438). The peculiarity of structured input is that it is purposefully tailored for attracting learners' attention to specific grammatical features. We admit that the evidence provided by VanPatten has to be taken into account for teaching L3 grammar after L2 in terms that the input has to be manipulated with the purpose of transfer enhancement.

The positive effects of processing instruction on the acquisition of the English past simple tense by native speakers of German learning English have been investigated by Benati and Angelovska (2015). Their study explored the effect of age and cognitive task demands on the results of the processing instruction. The processing instruction proved to be effective for both age groups (school-age children and young adults) and helped them to achieve accuracy in establishing connections between grammatical form and its meaning in tasks of different cognitive complexity. 
Though both age groups improved, the gains of school-age learners in the task with greater cognitive demand were not as high as adult learners' gains, which researchers explain by maturational constraints of the age. Overall outcomes remained positive (Benati \&Angelovska, 2015, pp. 265-267).

The specificity of input for teaching L3 grammar after L2 is that students have some linguistic knowledge and awareness of processing new grammatical structures. Hence one of the principles introduced by Ellis states that "Instruction needs to take into account the learner's 'built-in syllabus" (Ellis, 2005, p. 216; Ellis, 2014, p. 37-38). The author suggests that though grammar instruction may not guarantee that the explicit knowledge would transform into implicit, it has to be planned in accordance with the natural processes of language acquisition (Ellis, 2005, 2014). This principle is also to be taken into account in our investigation for the development of activities as far as teaching L3 grammar is to be based on the linguistic knowledge that learners already possess. The teacher has to pay attention to the metalinguistic knowledge generated by previous processes of acquisition of L1 and L2.

The exploration conducted by Angelovska (2017) views the role of students' prior language experience and shows that there is the necessity for teachers to be aware about the frequency of learners' exposure to prior languages, the social contexts of this exposure, which language should be regarded as dominant, and "to ensure that these realities find their reflection in instruction" (p. 399). Angelovska (2017) discusses "the input-practice-output (IPO) method" developed in cooperation with Hahn (p. 406). This method was developed to deal with negative syntactic transfer and the starting learning conditions were different as for some learners English was their first foreign language and the second for others. Authors consider the phase of the input as the most important one. This is the phase when the meaningful input designed, providing examples with triggers of negative transfer. Then follows the analysis of the differences and similarities in the selected sentences in both languages. The triggers are enhanced using textual enhancement, oral enhancement, and input flooding. The second phase of the IPO method presupposes collaborative practice that entails exchange of metalinguistic information and teacher's feedback that in its turn represents improved input. And then goes the phase of output production (Angelovska, 2017, p. 408-410).

Larsen-Freeman (2014) viewing the issue of form in grammar suggests that it embraces the range of notions from inflexions to certain patterns and syntactic structures. Thus, the term "constructions" used in linguistics to present the variety of morphologic and syntactic structure and patterns (Tomasello, 2003, as cited in Larsen-Freeman, 2014, p. 258). Larsen-Freeman (2014) develops a framework of how constructions are to be dealt with. In order to develop accurate, meaningful and appropriate grammatical structures usage they are to be treated in terms of "(1) structure or form; (2) semantics or meaning, and (3) use or the pragmatic conditions governing appropriate usage (LarsenFreeman, 2014, p. 258). The notion of grammaring introduced by Larsen-Freeman (2014) defines the purpose of grammar instruction as "the ability to use grammar constructions accurately, meaningfully, and appropriately" (p. 264). So, Larsen-Freeman (2014) supports the idea of the importance of output in teaching grammar and the necessity to provide conditions for practice so that learners could learn to convey meaning using appropriate grammatical form and constructions.

Developing the idea of the role of output one more principle provided by Ellis $(2005,2014)$ states that "Successful instructed language learning also requires opportunities for output" $(2005, \mathrm{p}$. $218 ; 2014$, p. 39). The author emphasizes that better opportunities for output occur during interactions in the classroom, on the contrary to controlled practice exercises that are limiting as to the choice of words and the length of structures (Ellis, 2005, p. 218-219; Ellis, 2014, p. 39). We consider that this principle has to be observed in the process of L3 grammar teaching because it helps learners gain more confidence in using new grammatical structures, develop their fluency in speaking and writing skills.

So, the input for teaching L3 grammar can warn students against misinterpreting the meaning the grammatical form conveys if there are differences in language systems of the previous language and the next one. On the other hand, it can show similarities in the grammar systems that serve for positive transfer. Practice and output help to utilize the gained knowledge which in its turn facilitates internalization of production patterns. While practising usage of grammatical forms students receive corrective feedback from the teacher, so they can check the accuracy of production and introduce necessary modifications in their conception of a certain construction. Benati (2017) states that output has a significant function of improving the automaticity of students' language use skills.

We suggest that explicit explanation of the grammatical structure has to show the connections with the prior languages learned by students or to show the absence of corresponding structures and how the meaning is delivered in the native (L1) or first foreign languages (L2). 
We view the enhancement of input as an important part of L3 grammar instruction process for the learners of English after German. The exposure to structures has to be multiple and the differences in language systems have to be salient. In our case, the example of textual enhancement can be used for the explicit presentation of grammatical forms when it is necessary to illustrate the structural, semantic and syntactic differences or similarities in English and German languages.

Thus, explanation of the Present Perfect Tense form can be illustrated with the following comparison of English sentences with German sentences where capitalization is used as text enhancement of important words for understanding.

Present Simple Tense

English: I KNOW you.

German: Ich KENNE dich.
Present Perfect Tense

English: I HAVE KNOWN you for years.

German: Ich KENNE dich SCHON seit Jahren.

The example of Present Perfect is also aimed at showing the meaning that Present Perfect in English conveys since its structure resembles the structure of German Perfekt, but the meaning in the English language is connected with the present. German Perfekt used in narratives conveys the reference to "definite moments in the past" (König \& Gast, 2012, p. 88). While in English only the use of Past Simple Tense is possible in this case.

As Larsen-Freeman (2014) suggests, it is important for teachers to identify the most challenging aspects for students, when planning the process of instruction. Thus, presenting Present Perfect Tense in English it is necessary to show the differences in the use of auxiliary verbs forming the aspect of perfect in English and German. The most challenging thing would be to grasp the nuances of meaning.

König and Gast (2012) show instances where German Perfekt and English Present Perfect show resemblance in form and meaning. They define these cases as "existential use", "resultative perfect", and "hot-news perfect" (König \& Gast, 2012, p. 91). Using the table suggested by König and Gast (2012, p. 91) and supplying text enhancement, the comparison of tenses can be illustrated in the following way:

\section{Existential use Resultative perfect Hot-news perfect}

\section{Present Perfect Tense} I HAVE DRUNK coffee. Jane HAS LOST her glasses. Louis as a baby name HAS RISEN in popularity.

\section{Perfekt}

Ich HABE Kaffee GETRUNKEN. Jane HAT ihre Brille VERLOREN. Louis als Babyname HAT an Popularität GEWONNEN.

The following example of the structured input use demonstrates the possibilities of exposure of students to the forms of Past Simple Tense and Present Perfect Tense. The time implications are omitted, and learners have to choose the meaning the tense form conveys. Example 1 represents a referential activity. Learners are supposed to choose which structure conveys the meaning of past action and which implies that the action started in the unstated past and connected with the present moment. Developing the activities, we took into account the guidelines of VanPatten (1997, pp. 438443), the examples provided by Nassaji and Fotos (2011, pp. 30-34), activities used by Benati and Angelovska (2017, pp. 256-260).

\section{Example 1.}

Instruction: Read the sentences and decide which of them show that something happened last week and which of them show that the action is connected with the present.

They travelled a lot. Last week Before now

We have travelled throughout Ukraine.

Granny has cooked our favourite dish.

He cooked us a nice French meal.

They worked long hours.

We have worked together.

Tom has played in every match.

Jill played the piano.

Jack studied History at university.

He has studied the document carefully. 
VanPatten (1997) grounds the necessity for affective activities that involve learners personally and thus attract their attention to meaning. The following activity is developed using the examples suggested by Nassaji and Fotos (2011, pp. 32-33).

Example 2.

Instruction. a) Choose from the list what you have done this morning. b) Explain your choice with your groupmate and compare your responses.

I have drunk coffee.

I have had my breakfast.

I have read a book.

I have looked through a newspaper.

I have made my bed.

I have cleaned my teeth.

I have ironed my t-shirt.

I have fried an egg.

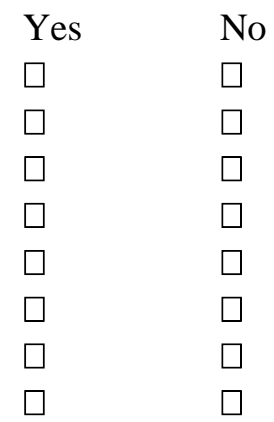

Further input processing presupposes practice that helps to convert the input into the intake. Considering the method proposed by Angelovska, the activities should be enriched with the tasks that develop metalinguistic knowledge (Angelovska, 2017). Following the ideas about "moving beyond the sentence level" in grammar teaching (Richards, 2015, p. 265) and the principles proposed by Richards and Reppen (2014), who substantiate the use of texts for grammar instruction, this activity should provide guided noticing (p. 13). As Hedge (2000) states, "In order for the learner to notice, the language feature has to be noticeable" (p. 146). That is why, in the following example, we used textual enhancement and highlighted by means of boldfacing the Present Perfect Tense forms.

Example 3.

Instruction. a) Read the text in English, pay attention to the Present Perfect Tense forms given in bold. Read the German translation of the text. Compare tense forms used in both texts.

b) Work in pairs, explain the usage of the Present Perfect Tense forms.

c) Put questions to the sentences with the verb forms given in bold.

Bill and Mary got married three years ago. They have known each other since they were at school. Last year they moved to England. Since then their life has changed. They have bought a new house. Bill has a new job. Mary writes short stories for a local magazine. She has already written 10 stories. They like travelling a lot. They have been to Italy and France and have seen many interesting places. They have never been to Greece and this is their next destination. So, they have already booked a flight to Athens. Bill and Mary enjoy their new life.
Bill und Mary haben vor drei Jahren geheiratet. Sie kennen sich seit ihrer Schulzeit. Letztes Jahr sind sie nach England gezogen. Seitdem hat sich ihr Leben verändert. Sie haben ein neues Haus gekauft. Bill hat eine neue Arbeit. Mary schreibt Kurzgeschichten für eine lokale Zeitschrift. Sie hat bereits 10 Geschichten geschrieben. Sie reisen sehr gern. Sie waren in Italien und Frankreich und haben viele interessante Orte gesehen. Sie waren noch nie in Griechenland und dies ist ihr nächstes Reiseziel. Sie haben also bereits einen Flug nach Athen gebucht. Bill und Mary genießen ihr neues Leben.

Thus, Example 3 presupposes possibilities for conscious comprehension of target tense forms. Learners have to trace the corresponding tense forms used in German text and give their reflections on how the meaning of pastness and connection with present is conveyed in English. Task b) in this activity is intended to help learners internalize the connection between the grammatical form and its meaning as well as to reflect on the context the target grammatical form used in. When doing task c), learners can manipulate the target grammatical form under changed conditions.

The development of productive grammatical skills is connected with output practice when students practice language use in oral or written form. As we have already mentioned, Richards and Reppen (2014) ground the importance of the usage of texts for teaching grammar. They view grammar as knowledge of rules and as the ability to produce texts using grammar as a resource for oral or 
written texts production. The authors claim that the presentation of grammatical rules is usually limited to the usage of a grammatical form in a separate sentence. Hence the traditional methodology of teaching grammar is mainly based on drills and practice of correct reproduction of sentences. While viewing grammar as a resource for the production of spoken or written discourse, the focus changes from the sentence to the text. Text is defined as "structured and conventional sequences of language that are used in different contexts in specific ways" (Richards \& Reppen, 2014, p. 6).

Regarding the issue of output, it is worth mentioning that grammar "needs to be taught and assessed as a component of communicative ability and performance - particularly in relation to the productive skills of writing and speaking" (Richards \& Reppen, 2014, p. 7). Hence it is necessary to elaborate the output activity that represents communication in a certain context and the usage of grammatical forms on the level of discourse.

Benati (2017) differentiates collaborative output tasks such as dictogloss or jigsaw tasks aimed at reconstructing a text and structured output tasks which are effective if they are preceded be structured input tasks (pp. 389-391). Supporting the view that "grammar is a tool for making meaning" (Thornbury, 1999, p.4), we consider that activities used for output have to promote learners' understanding of the meaning that can be expressed using particular grammatical forms.

We suggest that it is important to provide versatile scaffolding while developing output tasks, especially at the early stages of language learning, when learners do not possess enough linguistic means in the target language.

The following activity represents the output activity dedicated to the development of writing skills using the Present Perfect Tense form.

Example 4.

Instruction. Imagine that you are travelling around Europe. Write a letter to your friend using the Present Perfect Tense. Tell him or her where you have been, what you have seen and done.

a) Answer the following questions before writing:

1. What country are you in today?

2. How many countries have you visited so far?

3. What places have you visited?

4. What have you seen and done?

5. Have you tried any local food?

6. What has surprised you the most?

b) Use your answers and complete the letter.

Dear

I'm writing to you from I'm on a tour around Europe.

This is the seventh day of my journey.

\section{Truly yours,}

Example 4 demonstrates activity which can be used for speaking as well. Students can discuss the questions given in part a) during the class and write the letter at home.

Conclusions. Grammar instruction in teaching English after German has to be aimed at raising learners' grammatical awareness, developing learners' metalinguistic knowledge, using their previous linguistic knowledge as the basis for the positive transfer, and developing time preserving activities. Activities utilizing the structured input theory and input enhancement means are effective for presentation and explanation of a target grammatical form. These activities help students process the form or its structural peculiarities and, at the same time, they provide an understanding of meaning in communication. The proposed activities provide the tasks that involve the elements of perception and production as well as metalinguistic awareness development. The further automatization of grammatical skills is realized with the help of output-based activities providing production skills development in speaking or writing.

Further study is dedicated to the development of the model of forming productive grammatical competence of prospective teachers learning English after German within independent work. 


\section{REFERENCES}

1. Angelovska T. (2017). Beyond instructed L2 grammar acquisition: Theoretical insights and pedagogical considerations about the role of prior language knowledge. Studies in Second Language Learning and Teaching, 7(3), 397-417. https://doi.org/10.14746/ssllt.2017.7.3.3

2. Benati A. (2017). The role of input and output tasks in grammar instruction: Theoretical, empirical and pedagogical considerations. Studies in Second Language Learning and Teaching, 7(3), 377-396. https://doi.org/10.14746/ssllt.2017.7.3.2

3. Benati A., Angelovska T. (2015). The effects of Processing Instruction on the acquisition of English simple past tense: Age and cognitive task demands. International Review of Applied Linguistics in Language Teaching, 53(2), 249-269. https://doi.org/10.1515/iral-2015-0012

4. Ellis, R. (1997). Second Language Acquisition. Oxford: Oxford University Press

5. Ellis, R. (2005). Principles of instructed language learning. System. Vol. 33. Issue 2. $209-224$. https://doi.org/10.1016/j.system.2004.12.006

6. Ellis, R. (2014). Principles of Instructed Second Language Learning. In M. Celce-Murcia, D. M. Brinton, \& M. A. Snow (Eds.), Teaching English as a Second or Foreign Language (4th ed., pp. 31-45). Boston: National Geographic Learning

7. Hedge, T. (2000). Teaching and Learning in the Language Classroom. Oxford: Oxford University Press

8. König, E. \& Gast, V. (2012). Understanding English-German Contrasts (3., neu bearbeitete und erw. Aufl.). Berlin: Erich Schmidt Verlag

9. Larsen-Freeman, D. (2014). Teaching grammar. In M. Celce-Murcia, D. M. Brinton, \& M. A. Snow (Eds.), Teaching English as a Second or Foreign Language (4th ed., pp. 256-270). Boston: National Geographic Learning

10. Nassaji, H. \& Fotos, S. (2011). Teaching grammar in second language classrooms: integrating formfocused instruction in communicative context. New York: Routledge

11. Richards J. C. (2015). Key Issues in Language Teaching. Cambridge: Cambridge University Press

12. Richards, J. C., \& Reppen, R. (2014). Towards a Pedagogy of Grammar Instruction. RELC Journal, 45(1), 5-25. https://doi.org/10.1177/0033688214522622

13. Thornbury, S. (1999). How to teach grammar. Harlow, England: Pearson Education

14. VanPatten, B. (1993). Grammar Teaching for the Acquisition-Rich Classroom. Foreign Language Annals, 26(4), 435-450. https://doi.org/10.1111/j.1944-9720.1993.tb01179.x 